\title{
SOIL HYDRAULIC PROPERTIES AS INFLUENCED BY
}

\section{PRAIRIE RESTORATION}

\author{
Janith M. Chandrasoma ${ }^{\mathrm{a}}$, Ranjith P. Udawatta ${ }^{\mathrm{ab}}$, Stephen H. Anderson ${ }^{\mathrm{a}}$, \\ Allen L. Thompson ${ }^{\mathrm{c}}$, and Mark A. Abney ${ }^{\mathrm{d}}$ \\ ${ }^{a}$ Dept. of Soil, Environmental and Atmospheric Sciences, 302 Anheuser-Busch Natural Resources \\ Building, University of Missouri-Columbia, Columbia, MO 65211, USA. \\ b The Center for Agroforestry, 203 Anheuser-Busch Natural Resources Building, University of Missouri- \\ Columbia, Columbia, MO 65211, USA. \\ ${ }^{\mathrm{c}}$ Dept. of Biological Engineering, 251 Agricultural Engineering Building, University of Missouri- \\ Columbia, Columbia, MO 65211, USA. \\ ${ }^{\mathrm{d}}$ Clinton MLRA Soils Office, 1306 N, $2^{\text {nd }}$ Street, Clinton, MO 64735, USA.
}

\section{Corresponding Author:}

Janith M. Chandrasoma

Dept. of Soil, Environmental and Atmospheric Sciences,

302 Anheuser-Busch Natural Resources Building,

University of Missouri-Columbia,

Columbia,

MO 65211,

USA.

Tel +1 5736392711

E-mail: jmcgkd@mail.missouri.edu

(C) 2016. This manuscript version is made available under the Elsevier user license http://www.elsevier.com/open-access/userlicense/1.0/ 


\section{Abstract}

Prairie restoration has received increased public attention in recent years for its ecosystem services. The objective of this study was to evaluate effects of prairie restoration on soil hydraulic properties as compared to native prairie (NP), grass and rowcrop management. Soil cores $(76 \mathrm{~mm}$ diam. $\times 76 \mathrm{~mm}$ long) from six replicate locations were sampled to a $60-\mathrm{cm}$ depth at $10-\mathrm{cm}$ intervals from two prairie treatments, a continuous no-till treatment (NT), a long-term timothy grass (Phleum pratense L.) treatment (TM) and a row-crop (RC) treatment. The NP has never been tilled and the restored prairie (RP) was established in 1993. All treatments have Mexico silt loam (fine, smectitic, mesic, Vertic Epiaqualfs) soil. Bulk density, saturated hydraulic conductivity $\left(\mathrm{K}_{\mathrm{sat}}\right)$, soil water retention and pore size distribution were determined. In-situ $\mathrm{K}_{\mathrm{sat}}$ was measured using a constant head permeameter with five replications. Bulk density was significantly lower for NP than all treatments. Density was significantly lower for the 0 to $10 \mathrm{~cm}$ depth for all treatments, and the 10 to $30 \mathrm{~cm}$ depth recorded the highest values. The in-situ $\mathrm{K}_{\mathrm{sat}}$ of RP was lower than other treatments. The first horizon had the highest value for this parameter for all treatments. NP had significantly higher laboratory measured $\mathrm{K}_{\mathrm{sat}}$, and it was almost four times higher than RP. The 0 to $10 \mathrm{~cm}$ depth of all treatments had significantly higher values for laboratory $\mathrm{K}_{\mathrm{sat}}$ than other depths and the 50 to $60 \mathrm{~cm}$ showed the lowest $\mathrm{K}_{\mathrm{sat}}$. NP had the highest macroporosity and finemesoporosity, while RP had the highest microporosity. NP had significantly higher water retention at saturation while RP had the highest water retention for soil water pressures of $-33 \mathrm{kPa},-100 \mathrm{kPa}$ and $-1500 \mathrm{kPa}$. Soil water retention was significantly higher in NP for -

$0.4 \mathrm{kPa}$ to $-10 \mathrm{kPa}$ soil water pressures; at $-20 \mathrm{kPa} \mathrm{NP}, \mathrm{RP}$ and $\mathrm{RC}$ had significantly 
higher water retention. The NP treatment had higher soil water content than the other treatments for the 0 to $10 \mathrm{~cm}, 10$ to $20 \mathrm{~cm}, 20$ to $30 \mathrm{~cm}$ and 50 to $60 \mathrm{~cm}$ depths at soil water pressure of $-20 \mathrm{kPa}$. The 30 to $40 \mathrm{~cm}$ and 40 to $50 \mathrm{~cm}$ depths of RP had higher soil water content at all soil water pressures. Results imply that prairie restoration influences some hydraulic properties in claypan soils; however, it is unlikely to achieve the original prairie soil characteristics due to the prior erosion of the top soil.

Key words: bulk density, hydraulic conductivity, native prairie, restored prairie, soil erosion, soil health. 


\section{Introduction}

Prairie ecosystems are dominated by grasses and non-woody broad-leaf plants (forbs) with less than $10 \%$ tree cover where trees and other woody plants are either absent or widely scattered (Missouri Prairie Foundation, 2014). The importance of prairies has long been recognized and as a result many conservation attempts are being made to restore land to prairies. Goals of these conservation practices are to preserve biological diversity, aesthetic value and to reduce the negative impact of land practices on the environment. Recent interest in prairie restoration and its environmental benefits has encouraged the appraisal of restored prairies compared to native prairies and intensively cultivated areas in several regions of the USA (Mazurak et al., 1960; Udawatta et al., 2008). However restoration succeess can be affected by previous land use, initial soil conditions, topography, establishment and subsequent management procedures (Byre et al., 2008), degree of future management persistence (Kucharik, 2007) and time (Byre et al., 2002).

Prairies provide habitat for thousands of species of plants and animals (Byre et al., 2008). Studies have also shown that prairie soils have significantly greater quantities of soil organic carbon $(\mathrm{C})$, total $\mathrm{C}$, and nitrogen $(\mathrm{N})$; with low $\mathrm{pH}$, electrical conductivity, calcium (Ca) and phosphorous (Kucharik et al., 2006). A remnant prairie showed 37\% higher below-ground $\mathrm{C}$ than a 65-year-old restored prairie (Kucharik et al., 2006). McCulley et al., (2005) showed that prairies play a significant role in global flux of carbon dioxide $\left(\mathrm{CO}_{2}\right)$. Tallgrass prairies are well documented for their ability to accumulate higher amounts of organic matter particularly $\mathrm{C}$, due to deep extensive rooting (Follet et al., 2001). Furthermore, studies have shown that replacing annual crops 
with perennials have been known to change the quantity and quality of residue added to the soil (Wienhold and Tanaka, 2001). Prairies are also known for their improved soil hydraulic properties compared with conventional management systems.

Soil hydraulic properties are dynamic and influenced by many factors; those can be either physical, chemical or biological. Soil structure (Fuentes et al., 2004), shrinkswell cracks in clay soils (Baer and Anderson, 1997), and agricultural activities such as tillage and traffic compaction (Fuentes et al., 2004; Udawatta et al., 2008) are some physical factors that affect soil hydraulic properties. Plants and organisms that grow and decay also can alter soil hydraulic properties (Beven and Germann, 1982; Meek et al., 1992).

Soil physical properties can be degraded due to erosion (Lal and Moldenhauer, 1987; Arriaga and Lowery, 2003). Erosion removes the coarse-textured topsoil and exposes the fine-textured subsoil with higher bulk density and lower hydraulic conductivity (Seobi et al., 2005; Jagadamma et al., 2009). Perennial vegetation reduces the amount of surface runoff and the rate of erosion (van Rompaey et al., 2001) and thus perennial vegetation may cause differences in soil hydraulic properties. Schwartz et al. (2003) showed that land use practices also have a significant effect on water movement in soils compared to native prairie.

Saturated hydraulic conductivity is an essential parameter for understanding soil water movement. It is an important input for modeling runoff, drainage, and movement of solutes in soils (Mallants et al., 1997), and it is an important soil parameter which is highly influenced by soil management (Rachman et al., 2005; Udawatta et al., 2008). Natural prairies have been shown to increase hydraulic conductivity, organic matter 
content and lower soil bulk density values (Brye and Pirani, 2005; Brye and Moreno, 2006). Mazurak et al. (1960) reported that infiltration rates under perennial grasses in Nebraska approached those of a native grassland on a silt loam soil within 16 years of establishment. Studies conducted by Udawatta et al. (2008) using computed tomography reported that measured total number of pores, number of macropores ( $>1000 \mu \mathrm{m}$ diam.), macroporosity, mesoporosity (200 to $1000 \mu \mathrm{m}$ diam.), and fractal dimension of macroporosity were significantly higher and pore circularity was lower for native and restored prairies compared to continuous no-till management. Furthermore, soils under native prairie, restored prairie and no-till corn had 83, 43, and 26 pores on a 2500 $\mathrm{mm}^{2}$ area, respectively, for the 0 to $40 \mathrm{~cm}$ depth (Udawatta et al., 2008). Computed tomography measured soil pore parameters showed improvement in restored prairie compared to a no-till corn system (Udawatta et al., 2008).

In Missouri, Kremer and Anderson (2005) observed lower soil bulk densities for prairie soils as compared to a row-crop soil for the 0 to $10 \mathrm{~cm}$ soil depth. The difference was attributed to greater organic matter content in prairie soils.

Few studies have been conducted to evaluate soil physical and hydraulic properties to quantify beneficial effects of conservation efforts related to prairie restoration. A better knowledge of the soil water status and the movement of soil water could help develop better prairie restoration plans to improve overall environmental quality. We hypothesized that prairie restoration and long-term management practices can have a significant effect on soil hydraulic properties. The objective of this study was to quantify benefits of prairie restoration compared to a native prairie and long-term cultivated systems on soil water retention, pore-size distributions, bulk density, and 
saturated hydraulic conductivity. To test our hypothesis, soil physical and hydraulic properties were compared among a native prairie (NP) that has never been cultivated, a 21-year-old restored prairie (RP), a long-term timothy grass (TM) treatment, a continuous corn (Zea mays L.) under no-till cultivation (NT) treatment for 45 years and a treatment under row-crop (RC) cultivation for approximately 100 years.

\subsection{Materials and Methods}

\subsection{Experimental Sites}

All sites were located in central Missouri within the Central Claypan Area which occupies about $33,150 \mathrm{~km}^{2}$ in Missouri and Illinois (USDA, 2006). The native prairie (Tucker Prairie) is an untilled natural prairie (Dahlman and Kucera 1965). The native vegetation consists of big blue stem (Andropogon genardi Vitman.), little blue stem (Schizachyrium scoparium Nash.), prairie dropseed (Sporobolus heterolepis [A. Gray]), and Indian grass (Sorghastrum nutans [L. J. Nash]) (Udawatta et al., 2008). The burning process of the prairie was rotation burning and for the past decade the prairie was split into five sections and each section was burned twice every five years with one burning in the spring (March) and one in the fall ( September or October) as weather permits. The only source of soil disturbance in the prairie was due to small rodents, insects and microbial processes other than fire (Kucera et al., 1967).

The restored prairie (Prairie Fork) is a conservation area. This area was under row-crop management for nearly 150 years and was restored in 1993 with native grass and legumes (Udawatta et al., 2008). The restored prairie vegetation consisted of Indian grass (Sorghastrum nutans [L. J. Nash]), little blue stem (Schizachyrium scoparium Nash.) and side-oats gamma (Bouteloua curtipendula var. curtipendula) (Udawatta et al., 
2008). There are now about 260 native local ecotypes in the restored prairie. The burning of the restored prairie is rotation burning and the area is divided into three sections and each section is burned every three years.

The corn/soybean crop rotation, no-till continuous corn, continuous timothy, and cover crop treatments were under row-crop cultivation for approximately 150 years prior to present. The corn/soybean crop rotation treatment has been under conservation tillage for the past 30 years. During the earlier half of the $20^{\text {th }}$ century, this site was under plow and disk tillage and crops were wheat (Triticum aestivum L.) and corn. Corn, soybean (Glycine $\max$ L.) and grain sorghum (Sorghum bicolor L.) were cultivated during the latter part of the $20^{\text {th }}$ century with plow and disk tillage. The detailed historical management records of this site were documented by Lerch et al. (2005).

The no-till continuous corn treatment was managed under no-till management since 1970. The continuous timothy treatment was established over 125 years prior to sampling. The cover crop (CS) treatment was under cover crop management for the past 15 years. The management was cereal rye (Secale cereal) during the time of measurements. The cover crop treatment was only used to measure in-situ saturated hydraulic conductivity. No soil cores were obtained from this treatment for laboratory analysis.

Mexico silt loam (fine, smectitic, mesic, Vertic Epiaqualfs) is the major soil series for all study treatments. The parent material for soils in the selected study areas was loess over loamy sediments which developed from pre-Illinoisan till. Mexico soils are mostly located on ridges or hillsides with $0 \%$ to $4 \%$ slopes (Ghidey and Alberts, 1999). The presence of an argillic claypan (Fig. 1) horizon located between 10 and $30 \mathrm{~cm}$ below the 
surface is characteristic for these soils; they are therefore poorly drained (Ghidey and Alberts, 1999). Mean annual temperature ranges from 10 to $18^{\circ} \mathrm{C}$ and mean annual precipitation ranges from 890 to $1020 \mathrm{~mm}$ (http://climate.missouri.edu/). During winter and spring seasons, the water table is very shallow, and during summer the soil becomes very dry.

\subsection{Sample Collection and Analysis}

The treatments were located near each other. Due to land management constraints, the study used a pseudo-replication approach as has been used in other research with similar challenges. Soil sampling protocol was similar to method described by Byre and Riley. (2009). There are number of studies which had the similar challenge when sampling in these types of locations (Brye and Slaton, 2003; Brye and Pirani, 2005; Brye and Moreno, 2006).

Undisturbed soil cores were collected up to a $60 \mathrm{~cm}$ depth by $10 \mathrm{~cm}$ increments with six replicates. The core sampler was used to collect $7.6 \mathrm{~cm}$ diam. by $7.6 \mathrm{~cm}$ long soil cores. The sampler was driven manually with a slide hammer to collect each core sample. Each core sample was trimmed carefully and secured with plastic caps at each end using masking tape. Each core was labeled, placed in sealed plastic bags and transported to the laboratory in a wooden box. Samples were stored in a refrigerator at $4{ }^{\circ} \mathrm{C}$ until analyses were conducted. All samples were analyzed for texture, cation exchange capacity (CEC), soil organic matter and $\mathrm{pH}$ (Table 1, Fig. 1). All samples were collected between late May to early June in 2014.

Soil water retention, pore size distribution, bulk density and $\mathrm{K}_{\text {sat }}$ were measured for 180 soil cores ( 5 treatments X 6 replicates X 6 depths). The bottom of the cores was 
covered with cheese-cloth and then saturated in tubs with tap water (Electrical conductivity $=0.68 \mathrm{dS} / \mathrm{m}$; Sodium absorption ratio $=2.34$ ) before $\mathrm{K}_{\text {sat }}$ and water retention were measured. Visible pores and space between soil and the metallic rim were filled with applying bentonite-slurry (bentonite: water 8:1) with a syringe (Blanco-Canqui et al., 2002). The constant head method was used for $\mathrm{K}_{\text {sat }}$ determination and the falling head method was used on some samples with very low $\mathrm{K}_{\text {sat }}$ values (Klute and Dirksen, 1986).

Soil cores were re-saturated for water retention measurements. Water retention was measured using Buchner funnels for soil water pressures: 0.0, -0.4, -1.0, -2.5, -5.0, 10, and $-20 \mathrm{kPa}$ (Klute and Dirksen, 1986). From these water retention data, pore size distributions were calculated using the capillary rise equation to estimate effective pore classes (Jury et al., 1991). Pore size was divided into four classes: macropores (>1000 $\mu \mathrm{m}$ effective diam.), coarse-mesopores (60 to $1000 \mu \mathrm{m}$ effective diam.), fine-mesopores (10 to $60 \mu \mathrm{m}$ effective diam.), and micropores $(<10 \mu \mathrm{m}$ effective diam; Anderson et al., 1990). The corresponding soil water pressures were: macropores 0.0 to $-0.4 \mathrm{kPa}$, coarsemesopores -0.4 to $-5.0 \mathrm{kPa}$, fine-mesopores -5.0 to $-33 \mathrm{kPa}$ and micropores at $-33 \mathrm{kPa}$. The saturated core water content at $0 \mathrm{kPa}$ soil water pressure was used to determine total porosity. Soil cores were then air-dried for five to seven days at $35^{\circ} \mathrm{C}$ until a constant weight. A sub-sample was oven-dried at $105^{\circ} \mathrm{C}$ for 48 hours to determine water content and this water content was used to determine soil bulk density. Air-dried cores were then used for further water retention measurements of $-33,-100$ and $-1500 \mathrm{kPa}$ soil water pressures (Klute, 1986). The -33 and $-100 \mathrm{kPa}$ pressure measurements were conducted on soil aggregates, while the $-1500 \mathrm{kPa}$ used $2 \mathrm{~mm}$ sieved soil material. 


\subsection{In situ Conductivity Measurements}

In-situ measurements were taken in all treatments except $\mathrm{RC}$, and the cover crop (CS) site from mid-April to mid-June, 2014. Before installing Amoozemeters, the soil profile was characterized. A $1.5 \mathrm{~m}$ long soil core was taken with either a hydraulic probe or push probe to identify distinct soil horizons in each location. Once the soil horizons were identified, augur holes were dug to the required depth for each horizon. Each horizon was replicated five times. The in-situ procedure involved augering a cylindrical 6 cm diameter hole (r) to the desired depth, establishing a constant head $(\mathrm{H})$ such that $\mathrm{H} / \mathrm{r}$ > 5 and monitoring the outflow from the device until a steady-state flow rate was attained. At this point, $\mathrm{K}_{\text {sat }}$ was calculated via the Glover solution (Amoozegar, 1989a), which considers only the saturated flow component from the auger hole. Additional information on instrumentation and data collection can be found in Amoozegar (1989a).

\subsection{Statistical Analysis}

Analysis of variance (ANOVA) was conducted using the General Linear Model (GLM) procedure (SAS Institute, 2013) to test differences between treatments, depths and treatment by depth interactions. We tested the hypothesis that prairie restoration had significant effects on soil hydraulic properties. Differences between treatment and depth means were declared significant at the $95 \%$ probability level.

\section{Results and Discussion}

\subsection{Soil Water Retention}

Results of the analysis of variance for soil water retention are shown in Table 2. The results show treatments, sampling depths and treatment by depth interactions (treatment $\mathrm{x}$ depth) had significant effects on soil water content at all pressures measured. Soil water content at saturation was highest for the NP treatment and lowest for the NT 
treatment. Plant roots, added organic matter from the decay of these roots and little anthropogenic disturbance may have resulted in better soil structure in the NP compared to NT treatments and these effects may have resulted in the higher water content noticed at saturation in NP compared to NT. The higher value for RP compared to TM, NT and $\mathrm{RC}$, could be due to high clay content in subsurface horizons which may have been exposed by erosion (Fig. 1). Water content was higher in NP between -0.4 and $-10 \mathrm{kPa}$ compared to all other treatments. At $-20 \mathrm{kPa}$ pressure, water content was lowest in NP compared to the other treatments. Water content values at $-33,-100$ and $-1500 \mathrm{kPa}$ were significantly higher for RP compared to other treatments (Table 2). This could be attributed to the clay content in the subsoil exposed due to prior erosion (Fig. 1). We presume that the erosion of the top soil in RP was due to previous agricultural activities such as tillage and exposure to raindrop impact and runoff. Comparing water retention for silt loam (Albaqualf) soil under cultivation for 30 years and a virgin prairie, Scott and Wood (1989) found no significant differences in soil water retention at -30 and $-1,500$ $\mathrm{kPa}$ soil water pressures, whereas water retention was significantly different at other pressures. Water retention is influenced by soil, management, and carbon content and these may have contributed to differences observed between the two studies (Rawls et al., 2003).

The NP treatment had significantly higher water content compared to other treatments between 0 and $-0.4 \mathrm{kPa}$ pressures at the 0 to 10 and 10 to $20 \mathrm{~cm}$ depths. The RP treatment had higher water content at all pressures measured compared to other treatments (Fig. 2). Differences in soil water retention for the first three depths among all treatments could be attributed to variations in management; however for deeper depths, 
differences were more dependent on clay content (Fig. 1). Higher root density of the perennial grasses and forbs may have improved soil structure in the soil surface layers of the NP, RP and TM treatments as compared to NT and RC.

\subsection{Pore Size Distribution}

Table 3 shows the results of pore size distribution analysis for the various treatments. Results show that land management and treatment $\mathrm{x}$ depth interactions significantly affected distributions of all pore size classes while sampling depth significantly affected coarse and fine mesopores and micropores (Table 3). NT had significantly lower macroporosity compared to other treatments. This suggests that no-till management and long-term grass cover may not improve the proportion of soil macropores which will increase surface runoff and sediment loss. Packer et al. (1992) noted that even with stubble incorporation runoff did not decrease for a similar treatment. Native prairie had numerically higher macroporosity compared to other treatments and this may have contributed to the higher water content noticed for this treatment at 0 and $0.4 \mathrm{kPa}$ pressures. Higher macroporosity helps to decrease surface runoff and sediment loss. In fact studies conducted in loamy textured soils have shown that decreases in runoff are due to the improvement and maintenance of porosity, particularly macropores (Packer et al., 1992). Furthermore, studies have shown tillage and stubble burning have significantly decreased porosity, particularly macroporosity (> $60 \mu \mathrm{m}$; Zhang et al., 2007) which will eventually increase surface runoff and sediment erosion.

In a similar study conducted on a Putnam silt loam (claypan) soil, Seobi et al. (2005) showed no significant differences in macroporosity between a row-crop field and an agroforestry buffer. However, x-ray computed tomography (CT) measured 
macroporosity was found to be significantly higher for native prairie and Conservation Reserve Program (CRP) than for soils under row-crop cultivation (Udawatta et al., 2008). Gantzer and Anderson, (2002) showed the CT method is better in detecting macroporosity; however, it does not provide good estimates for the full range of mesopores. Differences observed among porosity for these studies could be also due to the estimation method.

Coarse-mesoporosity was significantly lower in RC compared to other treatments. Long-term soil management treatments (NT and TM), RP and NP showed similar coarsemesoporosity (Table 3). Highest fine-mesoporosity values were observed for NP and TM while RP showed the lowest. Results from the current study support the fact that soils which were under native vegetation (grass) tend to have higher number of finemesopores. Fine-mesoporosity for RP and NT was significantly lower compared to other treatments. Prairie restoration showed less improvement in fine-mesopores compared to a native prairie. This suggests that taking land out of prairie for agricultural production may negatively affect mesoporosity and this effect may not be reversed even if the land is restored to a prairie system. The highest microporosity was recorded in RP and the lowest was in TM. Microporosity was greater in RP than NP, TM and NT treatments. The difference could be due to higher clay content in RP compared with other treatments due to erosion of top soil with time and exposure of the claypan. The difference in clay content further supports the argument of greater topsoil loss from the RC treatment, which has been under cultivation for over 100 years (Lerch et al., 2005).

Pore size classes changed with soil depth except macroporosity (Table 3). Macropore distributions followed a similar pattern in all treatments except RP (Fig. 3). 
The restored prairie showed higher macroporosity values for the second (10 to $20 \mathrm{~cm}$ ) and third $(20$ to $30 \mathrm{~cm}$ ) depths. A study conducted in a clay soil comparing 30-year old trees with grass pasture showed no significant increase in macroporosity, except in one of the two soils, where significant differences occurred at the 25 to $35 \mathrm{~cm}$ depth (Messing et al., 1997). Another study showed warm season grasses significantly increased macroporosity compared to row-crop areas in the top $20 \mathrm{~cm}$ of a deep loess soil (Rachman et al., 2004). Coarse and fine mesoporosity were greater for the first depth (0 to $10 \mathrm{~cm}$ ) for all treatments. There were no variations in coarse-mesoporosity from the 10 to $40 \mathrm{~cm}$ depth and fine-mesoporosity from the 10 to $60 \mathrm{~cm}$ depth. 


\subsection{Bulk Density}

Results of bulk density for the treatments are shown in Table 4. Bulk density was significantly different among the treatments, soil depths, and also for the interaction between treatments and soil depth (Table 4). Averaged over all depths, bulk density was lower for the NP treatment than other treatments, and the RC had the highest bulk density value. This is in concert with the higher macroposority and water content (at 0 and -0.4 $\mathrm{kPa}$ pressures) noticed in NP compared with other treatments. No-till practices adopted for 30 years showed a slight reduction in overall bulk density as compared to RC however, values were not significant. The impact of long-term row-crop management on bulk density can be clearly seen in the increased bulk density values in RC compared to other management (Fig. 4). These differences can be attributed to heavy farm machinery use, tillage, and erosion (Rousseva et al., 1988; Or et al., 2000). Restored prairie had significantly lower bulk density compared with NT and RC. Results of the study showed that restoration of a continuously cropped treatment may have helped improve soil bulk density after 21 years from establishment.

Bulk density was significantly lower for the first depth $(0$ to $10 \mathrm{~cm})$ for all treatments (Table 4). The second and third depths (10 to $20 \mathrm{~cm}$ and 20 to $30 \mathrm{~cm}$ ) had the higher bulk density for all treatments; however, these values were not different from the fourth and fifth depths. These differences by depths were mainly due to differences in texture (Fig. 1) and structure. Higher root density at the first depth may have contributed to lower bulk density. Bulk density at the soil surface was less than $1 \mathrm{~g} \mathrm{~cm}^{-3}$ for the NP treatment. The average surface bulk density of RP, TM, and NT was $1.15 \mathrm{~g} \mathrm{~cm}^{-3}$ as compared to $1.44 \mathrm{~g} \mathrm{~cm}^{-3}$ for RC (Fig. 4). Restored prairie had the lowest bulk density for both fourth and fifth depths (Fig. 4) and those values were significantly different from 
TM. Similar trends were reported by Jiang et al. (2007). Management effects on bulk density occurred mainly in the first depth, and bulk density at the deeper depths was dominated by the clay content of the specific horizon (Jiang et al., 2007). Byre et al (2008) also noted soil bulk density in the top $10 \mathrm{~cm}$ ranged from $1.07 \mathrm{~g} \mathrm{~cm}^{-3}$ in native prairie to $1.23 \mathrm{~g} \mathrm{~cm}^{-3}$ in managed pastureland and 26-yr-old prairie restoration; values differed only slightly among considered ecosystems in their study.

\subsection{Laboratory Measured Saturated Hydraulic Conductivity}

Results of the saturated hydraulic conductivity $\left(\mathrm{K}_{\text {sat }}\right)$ for the various treatments are shown in Table 4 . Results showed that $\mathrm{K}_{\text {sat }}$ was significantly affected by treatment, sampling depth and treatment by depth interactions (treatment $\mathrm{x}$ depth). Averaged over all depths, NP had significantly higher $\mathrm{K}_{\text {sat }}$ when values were compared to other treatments. The $\mathrm{K}_{\text {sat }}$ value for the NP treatment was almost four times higher than for the $\mathrm{RP}$ treatment, and almost six times higher than for the NT treatment; these results are attributed to the lower bulk density and higher macroporosity noticed in NP. The $\mathrm{K}_{\text {sat }}$ values from the current study were lower compared to those reported by Fuentes et al. (2004) on Mollisols. In their study, $\mathrm{K}_{\text {sat }}$ values of soils under native prairie were almost 10 times higher than soils under conventional tillage and no-till management. Native prairie had approximately 20 times higher $\mathrm{K}_{\text {sat }}$ than $\mathrm{RC}$ and this suggests that NP may increase water infiltration into the soil compared to RC.

Long-term grass and restored prairie management showed slightly improved $\mathrm{K}_{\text {sat; }}$; however, values were not significantly different from RC. The row-crop management showed the lowest $\mathrm{K}_{\text {sat }}$ among treatments. Interestingly, the TM showed only about two times higher $\mathrm{K}_{\text {sat }}$ compared to RC. This may be due to lack of macropore development. 
This shows that prairie restoration can help improve profile water movement in continuously cultivated soils compared to continuous grass cover. This also shows higher diversity in plant species composition may improve water infiltration, reduce surface runoff and reduce sediment loss compared with a single species of grass cover.

The first depth $\left(0\right.$ to $10 \mathrm{~cm}$ ) had significantly higher $\mathrm{K}_{\text {sat }}$ compared to the other depths and it was two time higher than the second depth (Table 4). This is in concert with bulk density and pore size distribution results. The lowest $\mathrm{K}_{\mathrm{sat}}$ was recorded for the 50 to $60 \mathrm{~cm}$ depth where the claypan dominates (Table 4, Fig. 5B). Previous studies have shown a Bt 2 horizon from 45 to $65 \mathrm{~cm}$ in $\mathrm{RC}$ and a Bt1 from 41 to $56 \mathrm{~cm}$ in NP (Udawatta et al., 2008). Restored prairie also showed the same trend; $\mathrm{K}_{\mathrm{sat}}$ sharply declined beyond $50 \mathrm{~cm}$. In RP, the absence of a distinct $\mathrm{E}$ horizon may have reduced the $\mathrm{K}_{\text {sat }}$ in the first $30 \mathrm{~cm}$, while a thicker silt loam profile for NP has influenced higher water absorption. The $\mathrm{K}_{\mathrm{sat}}$ of NP was greater for the first three depths as compared to all other treatments. The RP also showed greater $\mathrm{K}_{\mathrm{sat}}$ for the 0 to $40 \mathrm{~cm}$ depth as compared to TM and RC (Fig. 5B). The $\mathrm{K}_{\mathrm{sat}}$ of all treatments dropped by 10 times for depths $>30 \mathrm{~cm}$ from the surface $96 \mathrm{~mm} \mathrm{hr}^{-1}$ value.

\subsection{In situ Saturated Hydraulic Conductivity}

Results of in situ saturated hydraulic conductivity are shown in Table5. In situ $\mathrm{K}_{\mathrm{sat}}$ was measured in the subsurface horizons. Results show that in situ $\mathrm{K}_{\mathrm{sat}}$ was significantly affected by treatment, horizon and treatment by horizon interactions (treatment $\mathrm{x}$ horizon). The in situ $\mathrm{K}_{\mathrm{sat}}$ was lower for the RP treatment than all other treatments when averaged across soil horizons. Depth one or the first horizon had a significantly higher $\mathrm{K}_{\text {sat }}$ compared to the other horizons across all treatments. Native 
prairie and TM had a distinct E horizon in their profile, while the other treatments consisted of a Bt1 horizon. Even though all treatments had the same soil series, there were distinct differences in horizonization probably due to past tillage and erosion. Interestingly, RP showed the lowest $\mathrm{K}_{\text {sat }}$ in Bt1 and Bt4 horizons (Fig. 5A).

In-situ measured $\mathrm{K}_{\text {sat }}$ values were different from the laboratory measured values (Fig. 5). This may be due to variability of the soil structure, type of clay and lateral water movement. Saturated hydraulic conductivity exhibits few spatial patterns, irrespective of sampling scale (Sobieraj et al., 2003); however, it can change by many orders of magnitude over short distances (Sobieraj et al., 2003). These differences could be due to heterogeneity of soil properties within and between soil horizons. This causes some regions to be more or less favorable to flow.

\section{Summary and Conclusions}

This study was conducted to evaluate the effect of prairie restoration on soil hydraulic properties compared to native prairie (NP), no-till (NT), continuous grass (TM) and row-crop (RC) treatments. Soil water retention, pore-size distribution, bulk density and both in-situ and laboratory measured saturated hydraulic conductivity were compared for the five treatments at six soil depths.

The restored prairie (RP) treatment had significantly lower in-situ $\mathrm{K}_{\text {sat }}$ than the other treatments. This difference was attributed to many structural and textural variations in the subsurface horizons. However, the exact reasons for the lower values are unclear and need further research. Laboratory measured $\mathrm{K}_{\text {sat }}$ was significantly higher under native prairie with RP having four times lower $\mathrm{K}_{\text {sat }}$ compared to native prairie. The restored prairie (RP) treatment had similar macroporosity and coarse-measoporosity, significantly 
greater microporosity and smaller fine-measoporosity compared to NP, TM, NT and RC treatments. These differences can be attributed to the higher root density of the perennial grasses and forbs and clay content in the subsoil. However, RP showed reduced soil bulk density and increased water content at the 0 to $-10 \mathrm{kPa}$ compared to NP. Significant differences among treatments existed for the first two sampling depths but not the lower four depths.

Results indicated that prairie restoration significantly influenced some hydraulic properties in claypan soils. However, it is unlikely to achieve the original prairie soil characteristics due to the prior erosion of the topsoil. Management effects were limited mainly to the surface 10 to $15 \mathrm{~cm}$ and the clay content of the specific horizon is believed to dominate soil hydraulic properties in deeper horizons.

\section{Acknowledgements}

We thank the Prairie Fork Foundation for financial support for this project. Additional support was provided by the Center for Agroforestry, University of Missouri, Columbia, MO. We extend special thanks to Grant Butler, USDA-NRCS for Amoozemeter installation. 


\section{References}

Amoozegar, A. 1989a. Comparison of the glover solution with the simultaneousequations approach for measuring hydraulic conductivity. Soil Sci. Soc. Am. J. 53(5): 1362-1367.

Amoozegar, A. 1989b. A compact constant-head permeameter for measuring saturated hydraulic conductivity of the vadose zone. Soil Sci. Soc. Am. J. 53(5): 1356-1361.

Anderson, S.H., C.J. Gantzer, and J.R. Brown. 1990. Soil physical properties after 100 years of continuous cultivation. J. Soil Water Conserv. 45(1): 117-121.

Arriaga, F.J., and B. Lowery. 2003. Soil physical properties and crop productivity of an eroded soil amended with cattle manure. Soil Sci. 168(12): 888-899.

Baer, J.U., and S.H. Anderson. 1997. Landscape effects on desiccation cracking in an aqualf. Soil Sci. Soc. Am. J. 61(5): 1497-1502.

Beven, K., and P. Germann. 1982. Macropores and water flow in soils. Water Resour. Res. 18(5): 1311-1325.

Blanco-Canqui, H., C.J. Gantzer, S.H. Anderson, E.E. Alberts, and F. Ghidey. 2002. Saturated hydraulic conductivity and its impact on simulated runoff for claypan soils. Soil Sci. Soc. Am. J. 66(5): 1596-1602.

Bouma, J. 1980. Field measurement of soil hydraulic properties characterizing water movement through swelling clay soils. J. Hydrol. 45(1): 149-158.

Brye, K.R., and T.L. Riley. 2009. Soil and plant property differences across a chronosequence of humid-temperate tallgrass prairie restorations. Soil Sci. 174:346357.

Brye, K.R., T.L. Riley, and E.E. Gbur. 2008. Prairie restoration effects on soil properties in the Ozark Highlands. J. Integr. Biosci. 6:87-104.

Brye, K.R., and L. Moreno. 2006. Vegetation removal effects on soil quality in a native tallgrass prairie fragment in east-central arkansas. Nat. Areas J. 26(1): 94-100.

Brye, K.R., and A.L. Pirani. 2005. Native soil quality and the effects of tillage in the grand prairie region of eastern Arkansas. Am. Midl. Nat. 154(1): 28-41.

Brye, K.R., and N.A. Slaton. 2003. Carbon and nitrogen storage in a typic albaqualf as affected by assessment method. Comm. Soil Sci. Plant Anal. 34:1637-1655. 
Brye, K.R., J.M. Norman, and S.T. Gower. 2002. Assessing the progress of a tallgrass prairie restoration in southern Wisconsin. Am. Midl. Nat. 148:218-235.

Dahlman, R.C., and C.L. Kucera. 1965. Root productivity and turnover in native prairie. Ecology: 84-89.

Follet, R.F., S.E. Samson-Liebig, J.M. Kimble, E.G. Preussner, and S.W. Waltman. 2001. Carbon sequestration under the CRP in the historic grassland soils of the USA. pp. 27-49. In R. Lal et al. (eds.) Soil management for enhancing carbon sequestration. SSSA Spec. Publ. 57. SSSA, Madison, WI.

Fuentes, J.P., M. Flury, and D.F. Bezdicek. 2004. Hydraulic properties in a silt loam soil under natural prairie, conventional till, and no-till. Soil Sci. Soc. Am. J. 68(5): 1679.

Gantzer, C.J., and S.H. Anderson. 2002. Computed tomographic measurement of macroporosity in chisel-disk and no-tillage seedbeds. Soil Tillage Res. 64(1): 101111.

Gantzer, C.J., S.H. Anderson, A.L. Thompson, and J.R. Brown. 1990. Estimating soil erosion after 100 years of cropping on Sanborn Field. J. Soil Water Conserv. 45(6): 641-644.

Ghidey, F., and E.E. Alberts, 1999. Temporal and spatial patterns of nitrate in a claypan soil. Journal of environmental quality. 28(2): 584-594.

Jagadamma, S., R.Lal, and B.K. Rimal. 2009. Effects of topsoil depth and soil amendments on corn yield and properties of two Alfisols in central Ohio. J. Soil Water Conserv. 64(1): 70-80.

Jamison, V.C., and D.B. Peters. 1967. Slope length of claypan soil affects runoff. Water Resour. Res. 3(2): 471-480.

Jiang, P., S.H. Anderson, N.R. Kitchen, E.J. Sadler, and K.A. Sudduth. 2007. Landscape and conservation management effects on hydraulic properties of a claypan-soil toposequence. Soil Sci. Soc. Am. J. 71(3): 803-811.

Jury, W.A., W.R. Gardner, and W.H. Gardner. 1991. Soil Physics, 328 pp. John Wiley Sons, Inc., New York 276: 345-348.

Kremer, R.J., and S.H. Anderson. 2005. Characterizing soil quality during restoration of prairie ecosystems. Report to Missouri Dep. of Conservation, Jefferson City, Missouri, USA. 
Klute, A. 1986. Water retention: laboratory methods. Methods Soil Anal. Part 1Physical Mineral. Methods (methodsofsoilan1): 635-662.

Klute, A., and C. Dirksen. 1986. Hydraulic conductivity and diffusivity. Laboratory methods. p. 687-734. In Methods of soil analysis - part 1. Physical and mineralogical methods. American Society of Agronomy, Madison, WI 53711.

Krusekopf, H.H., and C.L. Schrivner. 1962. Soil Survey of Boone county, Missouri. Department of Agriculture, Soil Conservation Service.

Kucera, C.L., R. Dahlman, and M. Koelling. 1967. Total net productivity and turnover on energy basis for tallgrass prairie. Ecology 48:536-541.

Kucharik, C.J. 2007. Impact of prairie age and soil order on carbon and nitrogen sequestration. Soil Sci. Soc. Am. J. 71:430-441.

Kucharik, C.J., N.J. Fayram, and K.N. Cahill. 2006. A paired study of prairie carbon stocks, fluxes, and phenology: Comparing the world's oldest prairie restoration with an adjacent remnant. Glob. Chang. Biol. 12(1): 122-139.

Lal, R., and W.C. Moldenhauer. 1987. Effects of soil erosion on crop productivity. CRC. Crit. Rev. Plant Sci. 5(4): 303-367.

Lerch, R.N., N.R. Kitchen, R.J. Kremer, W.W. Donald, E.E. Alberts, E.J. Sadler, K.A. Sudduth, D.B. Myers, and F. Ghidey. 2005. Development of a conservation-oriented precision agriculture system: Water and soil quality assessment. J. Soil Water Conserv. 60(6): 411-421.

Mallants, D., B.P. Mohanty, A. Vervoort, and J. Feyen. 1997. Spatial analysis of saturated hydraulic conductivity in a soil with macropores. Soil Technol. 10(2): 115-131.

Mazurak, A.P., K. Willis, and R.E. Raming. 1960. Rates of water entry into Chernozem soil as affected by age of perennial grass sods. Agron. J. 52: 35-37.

McCulley, L.R., I.C. Burke, J.A. Nelson, W.K. Lauenroth, A.K. Knapp, and E.F. Kelly. 2005. Regional patterns in carbon cycling across the Great Plains of North America. Ecosystems 8:106-122.

Meek, B.D., E.R. Rechel, L.M. Carter, W.R. DeTar, and A.L. Urie. 1992. Infiltration rate of a sandy loam soil: effects of traffic, tillage, and plant roots. Soil Sci. Soc. Am. J. 56(3): 908-913. 
Messing, I., A. Alriksson, and W. Johansson. 1997. Soil physical properties of afforested and arable land. Soil Use Manage. 13:209-217.

Missouri Prairie Foundation., 2014. Education and outreach. Retrived from http://www.moprairie.org/educational-resources/.

Missouri Climate Center., 2014. Retrived from http://climate.missouri.edu/.

Or, D., F.J. Leij, V. Snyder, and T.A. Ghezzehei. 2000. Stochastic model for posttillage soil pore space evolution. Water Resour. Res. 36(7): 1641.

Packer, I. J., G. J. Hamilton, and T. B. Koen. 1992. Runoff, soil loss and soil physical property changes of light textured surface soils from long term tillage treatments. Soil Research, 30(5): 789-806.

Rachman, A., S.H. Anderson, and C.J. Gantzer. 2005. Computed-tomographic measurement of soil macroporosity parameters as affected by stiff-stemmed grass hedges. Soil Sci. Soc. Am. J. 69(5): 1609-1616.

Rawls, W. J., Y. A. Pachepsky, J. C. Ritchie, T. M. Sobecki and H. Bloodworth. 2003. Effect of soil organic carbon on soil water retention. Geoderma 116(1): 61-76.

van Rompaey, A., G. Verstraeten, K. Van Oost, G. Govers, and J. Poesen. 2001. Modelling mean annual sediment yield using a distributed approach. Earth Surf. Process. Landforms 26(11): 1221-1236.

Rousseva, S.S., L.R. Ahuja, and G.C. Heathman. 1988. Use of a surface gamma-neutron gauge for in situ measurement of changes in bulk density of the tilled zone. Soil Tillage Res. 12(3): 235-251.

SAS (Statistical Analysis Systems) Institute Inc. 2013. SAS user's guide. Statistics. SAS Instit., Cary, NC.

Schwartz, R.C., S.R. Evett, and P.W. Unger. 2003. Soil hydraulic properties of cropland compared with reestablished and native grassland. Geoderma 116(1-2): 47-60.

Scott, H.D., and L.S. Wood. 1989. Impact of crop production on the physical status of a Typic Albaqualf. Soil Sci. Soc. Am. J. 53(6): 1819-1825.

Seobi, T., S.H. Anderson, R.P. Udawatta, and C.J. Gantzer. 2005. Influence of grass and agroforestry buffer strips on soil hydraulic properties for an Albaqualf. Soil Sci. Soc. Am. J. 69(3): 893-901. 
Sobieraj, J. A., H. Elsenbeer, and G. Cameron. Scale dependency in spatial patterns of saturated hydraulic conductivity. Catena. 2004 Jan 5;55(1):49-77.

Udawatta, R.P., S.H. Anderson, C.J. Gantzer, and H.E. Garrett. 2008. Influence of prairie restoration on CT-measured soil pore characteristics. J. Environ. Qual. 37(1): 219228.

U.S. Department of Agriculture (USDA). 2006. Land resource regions and major land resource areas of the United State, the Carribbean, and the Pacific Basin. pp. 357USDA Agricultural Handbook Number 296. Washington, DC.

Wienhold, B.J., and D.L. Tanaka. 2001. Soil property changes during conversion from perennial vegetation to annual cropping. Soil Sci. Soc. Am. J. 65(6): 1795-1803.

Zhang, G. S., K. Y. Chan, A. Oates, D. P. Heenan, and G. B. Huang. 2007. Relationship between soil structure and runoff/soil loss after 24 years of conservation tillage. Soil and Tillage Research, 92(1): 122-128. 
Table 1. Soil properties for the native prairie (NP), restored prairie (RP), timothy grass (TM), no-till corn (NT) and row-crop (RC) treatments.

\begin{tabular}{|c|c|c|c|c|}
\hline $\begin{array}{c}\text { Soil } \\
\text { Horizon }\end{array}$ & Soil depth & CEC & $\begin{array}{c}\text { Organic } \\
\text { carbon }\end{array}$ & $\begin{array}{c}\mathrm{pH} \\
\text { (Water) }\end{array}$ \\
\hline & $\mathrm{cm}$ & $\mathrm{cmol} \mathrm{kg}^{1}$ & $\mathrm{~g} \mathrm{~kg}^{-1}$ & \\
\hline \multicolumn{5}{|c|}{ Native Prairie (NP) } \\
\hline A & 0-20 & 19.3 & 36 & 5.2 \\
\hline $\mathrm{AE}$ & $20-25$ & 14.3 & 13 & 5 \\
\hline $\mathrm{E}$ & $25-36$ & 14.8 & 9 & 4.9 \\
\hline $\mathrm{EB}$ & $36-41$ & 16.3 & 8 & 5 \\
\hline Bt1 & $41-56$ & 33 & 11 & 4.8 \\
\hline \multicolumn{5}{|c|}{ Restored Prairie (RP) } \\
\hline A & 0-19 & 19.2 & 17 & 6.4 \\
\hline $\mathrm{E}$ & $19-36$ & 25.7 & 10 & 6 \\
\hline Bt1 & $36-56$ & 32.1 & 8 & 5.2 \\
\hline \multicolumn{5}{|c|}{ Timothy Grass (TM) } \\
\hline A & $0-20$ & 11.1 & 17 & 5.3 \\
\hline $\mathrm{E}$ & $21-44$ & 10.7 & 9 & 5 \\
\hline Bt1 & $45-68$ & 17 & 9 & 4.6 \\
\hline \multicolumn{5}{|c|}{ No-till Corn (NT) } \\
\hline Ap & 0-13 & 13.5 & 23 & 5.1 \\
\hline Bt1 & $14-30$ & 12.6 & 15 & 5.2 \\
\hline $\mathrm{Bt} 2$ & $31-52$ & 13.5 & 7 & 5.1 \\
\hline $\mathrm{Bt} 3$ & $52-74$ & 21.2 & 8 & 4.7 \\
\hline \multicolumn{5}{|c|}{ Row-Crop (RC) } \\
\hline Ap & $0-7.5$ & 20.7 & 12 & 7.1 \\
\hline $\mathrm{AB}$ & $7.5-15$ & 24.0 & 10 & 5.9 \\
\hline Bt1 & $15-34$ & 31.7 & 8 & 5.1 \\
\hline Bt2 & $34-61$ & 38.3 & 7 & 5.0 \\
\hline
\end{tabular}


Table 2. Soil water retention for native prairie (NP), restored prairie (RP), timothy grass (TM), no-till corn (NT) and row-crop (RC) treatments and soil depths along with analysis of variance (ANOVA) and probability values $(\mathrm{P}>\mathrm{F})$ for measured soil water pressures. Means with different letters within a column are significantly different at the 0.05 probability level.

\begin{tabular}{|c|c|c|c|c|c|c|c|c|c|c|}
\hline & \multicolumn{10}{|c|}{ Soil water pressure $(\mathrm{kPa})$} \\
\hline & 0.0 & -0.4 & -1.0 & -2.5 & -5.0 & -10.0 & -20.0 & -33.0 & -100 & -1500 \\
\hline & & & & & 3 & & & & & \\
\hline \multicolumn{11}{|l|}{ Treatment mean } \\
\hline Native Prairie (NP) & $0.571^{\mathrm{a}}$ & $0.540^{\mathrm{a}}$ & $0.517^{\mathrm{a}}$ & $0.487^{\mathrm{a}}$ & $0.460^{\mathrm{a}}$ & $0.440^{\mathrm{a}}$ & $0.419^{\mathrm{a}}$ & $0.374^{b}$ & $0.278^{b}$ & $0.147^{\mathrm{cb}}$ \\
\hline Restored Prairie (RP) & $0.530^{b}$ & $0.514^{a b}$ & $0.478^{b}$ & $0.459^{b}$ & $0.442^{a b}$ & $0.433^{a b}$ & $0.423^{\mathrm{a}}$ & $0.420^{\mathrm{a}}$ & $0.343^{\mathrm{a}}$ & $0.269^{a}$ \\
\hline Timothy Grass (TM) & $0.516^{b}$ & $0.502^{b c}$ & $0.483^{b}$ & $0.452^{\mathrm{bc}}$ & $0.435^{\mathrm{b}}$ & $0.412^{b c}$ & $0.390^{b c}$ & $0.363^{\mathrm{b}}$ & $0.274^{\mathrm{b}}$ & $0.140^{c}$ \\
\hline No-till Corn (NT) & $0.486^{c}$ & $0.486^{b c}$ & $0.462^{b}$ & $0.447^{b c}$ & $0.425^{b c}$ & $0.394^{c}$ & $0.373^{c}$ & $0.371^{b}$ & $0.289^{b}$ & $0.171^{\mathrm{bc}}$ \\
\hline Row-crop (RC) & $0.510^{b c}$ & $0.484^{\mathrm{c}}$ & $0.463^{b}$ & $0.431^{c}$ & $0.408^{c}$ & $0.423^{a b}$ & $0.410^{a b}$ & $0.383^{b}$ & $0.303^{b}$ & $0.184^{b}$ \\
\hline \multicolumn{11}{|l|}{ Depth mean } \\
\hline 0 to $10 \mathrm{~cm}$ & $0.576^{\mathrm{a}}$ & $0.552^{\mathrm{a}}$ & $0.516^{\mathrm{a}}$ & $0.477^{\mathrm{ab}}$ & $0.447^{\mathrm{b}}$ & $0.427^{\mathrm{b}}$ & $0.401^{\mathrm{c}}$ & $0.345^{\mathrm{c}}$ & $0.255^{\mathrm{c}}$ & $0.135^{\mathrm{d}}$ \\
\hline 10 to $20 \mathrm{~cm}$ & $0.497^{\mathrm{cd}}$ & $0.480^{\mathrm{d}}$ & $0.457^{\mathrm{c}}$ & $0.432^{c}$ & $0.406^{\mathrm{cd}}$ & $0.388^{\mathrm{dc}}$ & $0.366^{\mathrm{d}}$ & $0.352^{\mathrm{c}}$ & $0.250^{\mathrm{c}}$ & $0.131^{\mathrm{d}}$ \\
\hline 20 to $30 \mathrm{~cm}$ & $0.493^{\mathrm{d}}$ & $0.475^{\mathrm{d}}$ & $0.454^{\mathrm{c}}$ & $0.427^{\mathrm{c}}$ & $0.400^{\mathrm{d}}$ & $0.384^{\mathrm{d}}$ & $0.363^{\mathrm{d}}$ & $0.359^{\mathrm{c}}$ & $0.269^{c}$ & $0.148^{\mathrm{d}}$ \\
\hline 30 to $40 \mathrm{~cm}$ & $0.504^{\mathrm{cd}}$ & $0.492^{\mathrm{cd}}$ & $0.466^{\mathrm{bc}}$ & $0.439^{c}$ & $0.420^{\mathrm{c}}$ & $0.406^{\mathrm{c}}$ & $0.390^{\mathrm{c}}$ & $0.385^{\mathrm{b}}$ & $0.305^{b}$ & $0.185^{c}$ \\
\hline 40 to $50 \mathrm{~cm}$ & $0.521^{\mathrm{bc}}$ & $0.501^{c}$ & $0.480^{b}$ & $0.460^{b}$ & $0.447^{b}$ & $0.440^{b}$ & $0.429^{b}$ & $0.399^{b}$ & $0.333^{b}$ & $0.232^{b}$ \\
\hline 50 to $60 \mathrm{~cm}$ & $0.544^{\mathrm{a}}$ & $0.532^{b}$ & $0.511^{\mathrm{a}}$ & $0.495^{\mathrm{a}}$ & $0.483^{\mathrm{a}}$ & $0.478^{\mathrm{a}}$ & $0.470^{\mathrm{a}}$ & $0.453^{\mathrm{a}}$ & $0.375^{\mathrm{a}}$ & $0.263^{\mathrm{a}}$ \\
\hline \multicolumn{11}{|c|}{ Analysis of variance $\mathrm{P}>\mathrm{F}$} \\
\hline Treatment & $<0.0001$ & $<0.0001$ & $<0.0001$ & $<0.0001$ & $<0.0001$ & $<0.0001$ & $<0.0001$ & $<0.0001$ & $<0.0001$ & $<0.0001$ \\
\hline Depth & $<0.0001$ & $<0.0001$ & $<0.0001$ & $<0.0001$ & $<0.0001$ & $<0.0001$ & $<0.0001$ & $<0.0001$ & $<0.0001$ & $<0.0001$ \\
\hline Treatment by Depth & $<0.0001$ & $<0.0001$ & $<0.0001$ & $<0.0001$ & $<0.0001$ & $<0.0001$ & $<0.0001$ & $<0.0001$ & $<0.0001$ & $<0.0001$ \\
\hline
\end{tabular}


Table3. Macroporosity, coarse mesoporosity, fine mesoporosity, microporosity for native prairie (NP), restored prairie (RP), timothy grass (TM), no-till corn (NT) and row-crop (RC) treatments by soil depth with analysis of variance (ANOVA). Means with different letters within a column are significantly different at the 0.05 probability level.

\begin{tabular}{|c|c|c|c|c|}
\hline \multirow[b]{2}{*}{ Treatment } & $\begin{array}{l}\text { Macroporosity } \\
(>1000 \mu \mathrm{m})\end{array}$ & $\begin{array}{l}\text { Coarse Mesoporosity } \\
(60 \text { to } 1000 \mu \mathrm{m})\end{array}$ & $\begin{array}{l}\text { Fine Mesoporosity } \\
\qquad(10 \text { to } 60 \mu \mathrm{m})\end{array}$ & $\begin{array}{l}\text { Microporosity } \\
\quad(<10 \mu \mathrm{m})\end{array}$ \\
\hline & \multicolumn{4}{|c|}{ - } \\
\hline \multicolumn{5}{|l|}{ Treatment mean } \\
\hline Native Prairie (NP) & $0.030^{\mathrm{a}}$ & $0.081^{\mathrm{a}}$ & $0.085^{\mathrm{a}}$ & $0.375^{\mathrm{b}}$ \\
\hline Restored Prairie (RP) & $0.025^{\mathrm{ab}}$ & $0.072^{\mathrm{a}}$ & $0.035^{\mathrm{c}}$ & $0.420^{\mathrm{a}}$ \\
\hline Timothy Grass (TM) & $0.020^{\mathrm{bc}}$ & $0.077^{\mathrm{a}}$ & $0.076^{\mathrm{ab}}$ & $0.363^{\mathrm{b}}$ \\
\hline No-till Corn (NT) & $0.014^{\mathrm{c}}$ & $0.078^{\mathrm{a}}$ & $0.046^{\mathrm{c}}$ & $0.371^{\mathrm{b}}$ \\
\hline Row-crop (RC) & $0.026^{\mathrm{ab}}$ & $0.049^{\mathrm{b}}$ & $0.052^{\mathrm{bc}}$ & $0.384^{\mathrm{ab}}$ \\
\hline \multicolumn{5}{|l|}{ Depth mean } \\
\hline 0 to $10 \mathrm{~cm}$ & $0.026^{\mathrm{a}}$ & $0.106^{\mathrm{a}}$ & $0.104^{\mathrm{a}}$ & $0.350^{\mathrm{d}}$ \\
\hline 10 to $20 \mathrm{~cm}$ & $0.023^{\mathrm{a}}$ & $0.071^{\mathrm{a}}$ & $0.058^{b c}$ & $0.360^{\mathrm{cd}}$ \\
\hline 20 to $30 \mathrm{~cm}$ & $0.024^{\mathrm{a}}$ & $0.074^{\mathrm{b}}$ & $0.043^{b c}$ & $0.362^{\mathrm{cd}}$ \\
\hline 30 to $40 \mathrm{~cm}$ & $0.023^{\mathrm{a}}$ & $0.070^{\mathrm{bc}}$ & $0.046^{\mathrm{bc}}$ & $0.381^{\mathrm{bc}}$ \\
\hline 40 to $50 \mathrm{~cm}$ & $0.024^{\mathrm{a}}$ & $0.057^{\mathrm{cd}}$ & $0.061^{\mathrm{b}}$ & $0.397^{b}$ \\
\hline 50 to $60 \mathrm{~cm}$ & $0.020^{\mathrm{a}}$ & $0.049^{\mathrm{d}}$ & $0.040^{\mathrm{b}}$ & $0.448^{\mathrm{a}}$ \\
\hline \multicolumn{5}{|l|}{ ANOVA $(\mathrm{P}>\mathrm{F})$} \\
\hline Treatment & 0.001 & $<0.001$ & $<0.001$ & $<0.001$ \\
\hline Depth & 0.892 & $<0.001$ & $<0.001$ & $<0.001$ \\
\hline Treatment by Depth & 0.001 & $<0.001$ & $<0.001$ & $<0.001$ \\
\hline
\end{tabular}




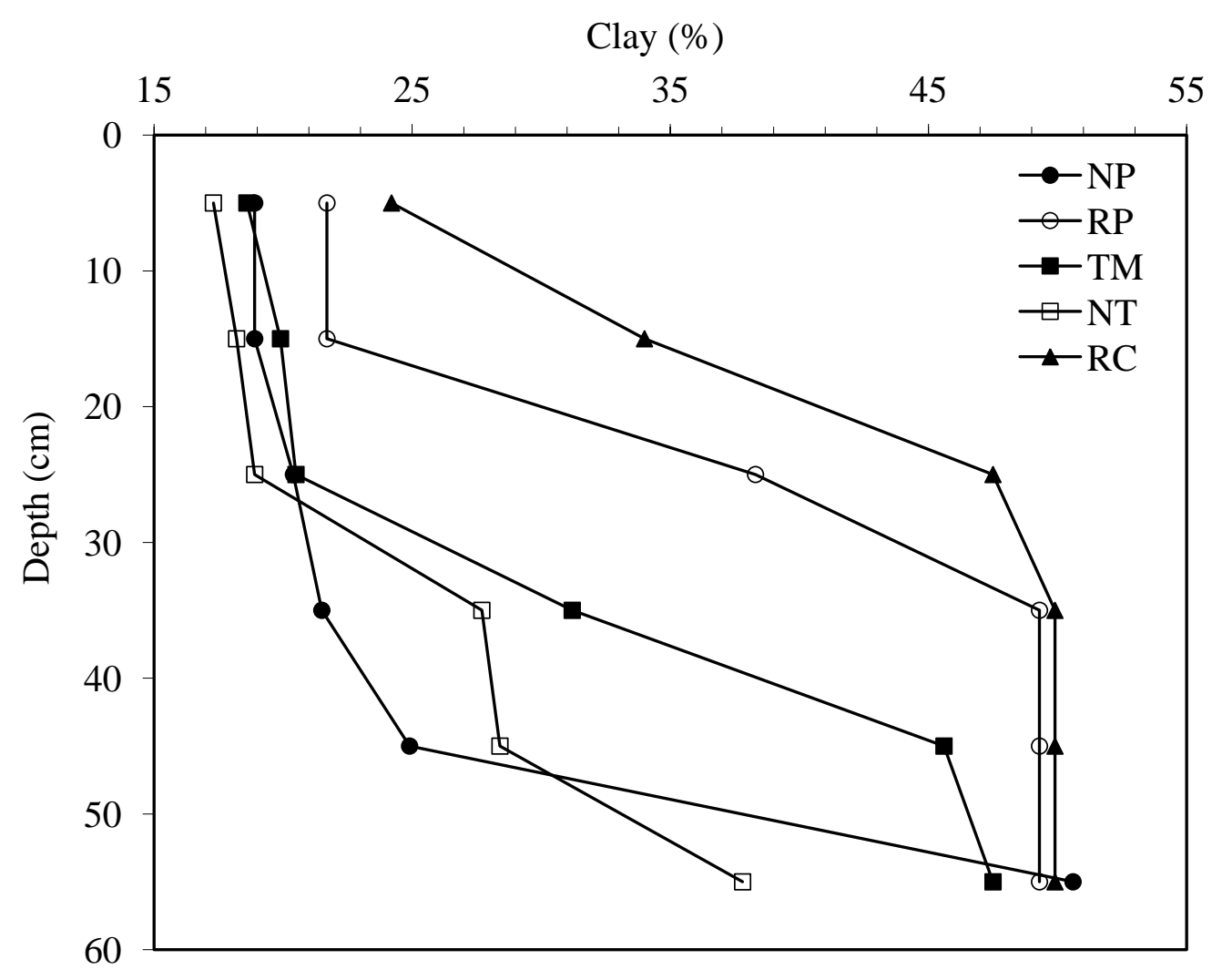

Figure 1. Clay percentage as a function of depth for native prairie (NP), restored prairie (RP), timothy grass (TM), no-till corn (NT) and row-crop (RC) treatments. 
0-10 cm depth

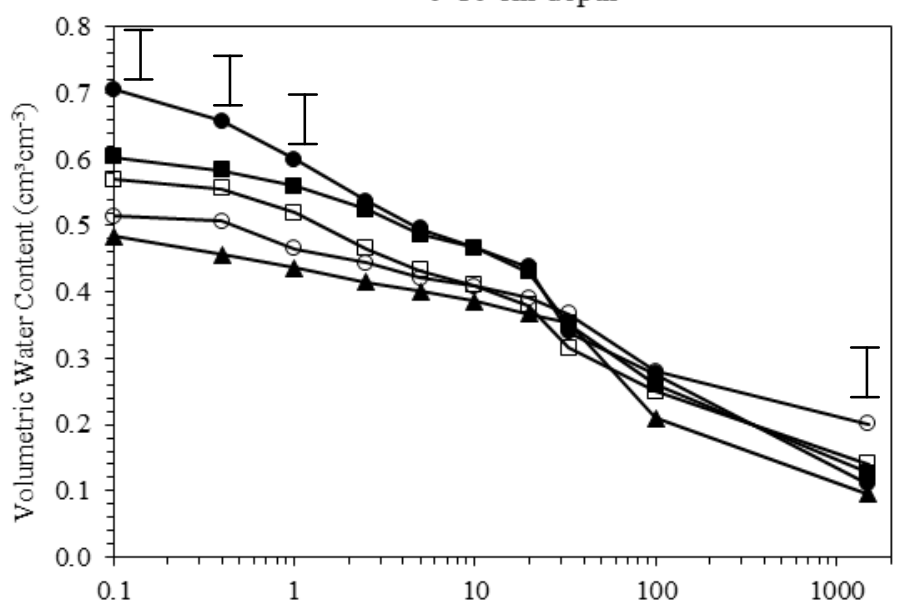

20-30 cm depth

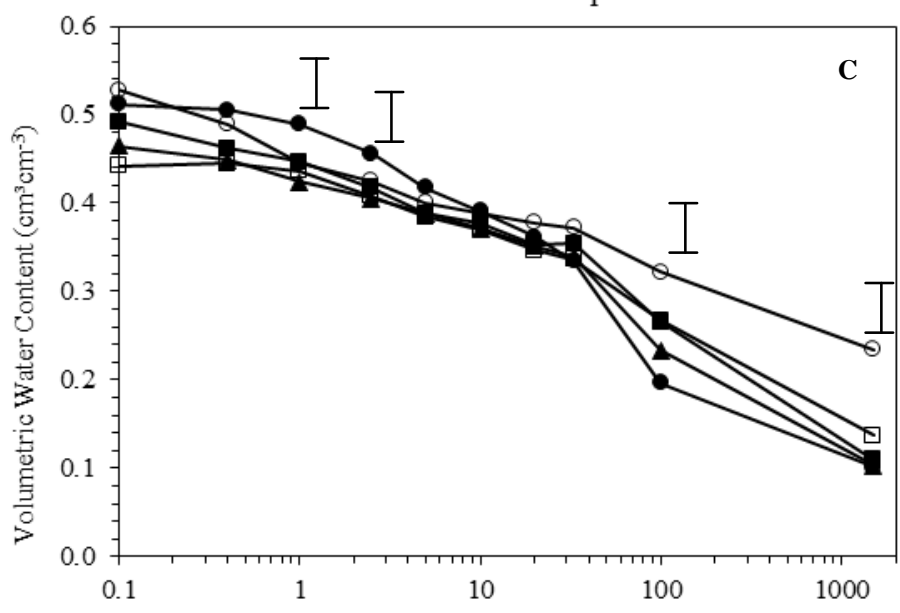

40-50 cm depth

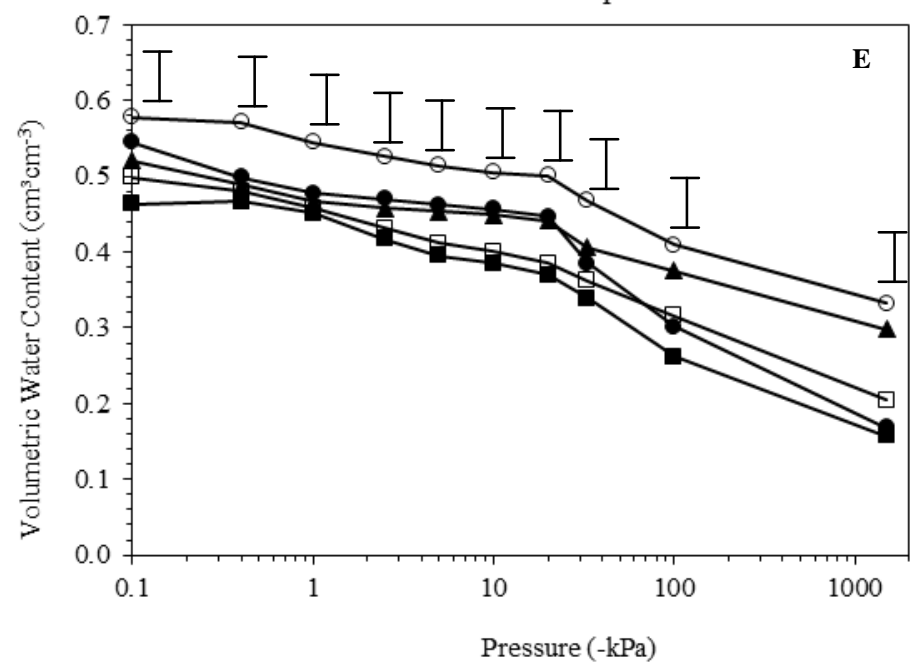

$10-20 \mathrm{~cm}$ depth

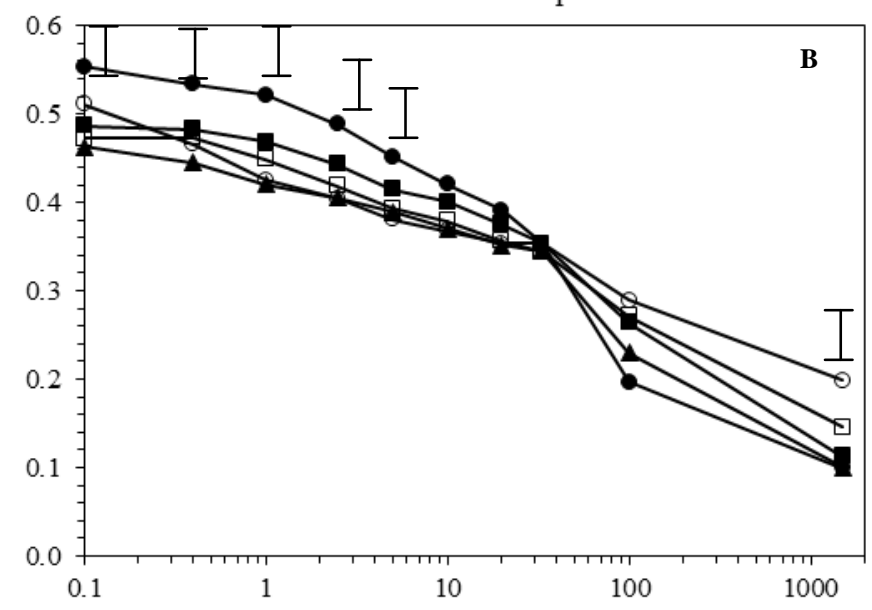

30-40 cm depth

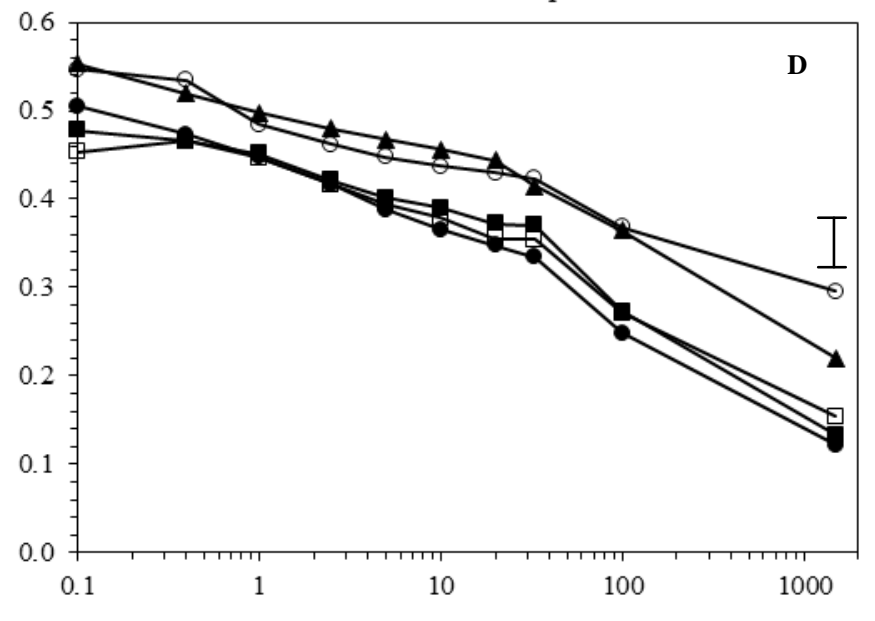

$50-60 \mathrm{~cm}$ depth

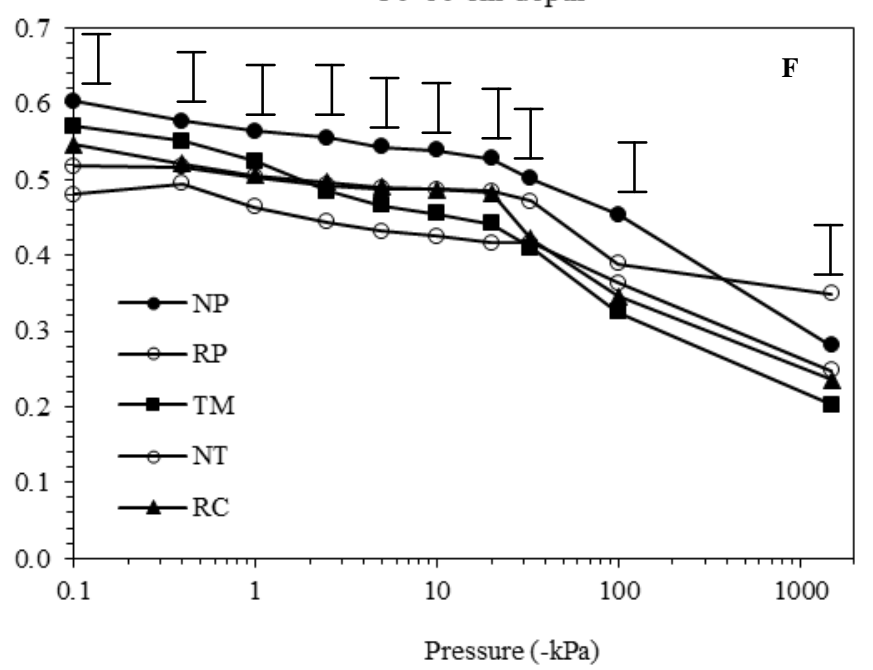

Figure 2. Soil water retention 0 to $10 \mathrm{~cm}$ (A), 10 to $20 \mathrm{~cm}$ (B), 20 to $30 \mathrm{~cm}$ (C), 30 to $40 \mathrm{~cm}$ (D), 40 to $50 \mathrm{~cm}$ (E), and 50 to $60 \mathrm{~cm}(\mathrm{~F})$ for native prairie (NP), restored prairie (RP), timothy grass (TM), no-till corn (NT) and row-crop (RC) treatments. Bars indicate least significant difference $(0.05)$ values for a specific soil water pressure when differences were significant. 

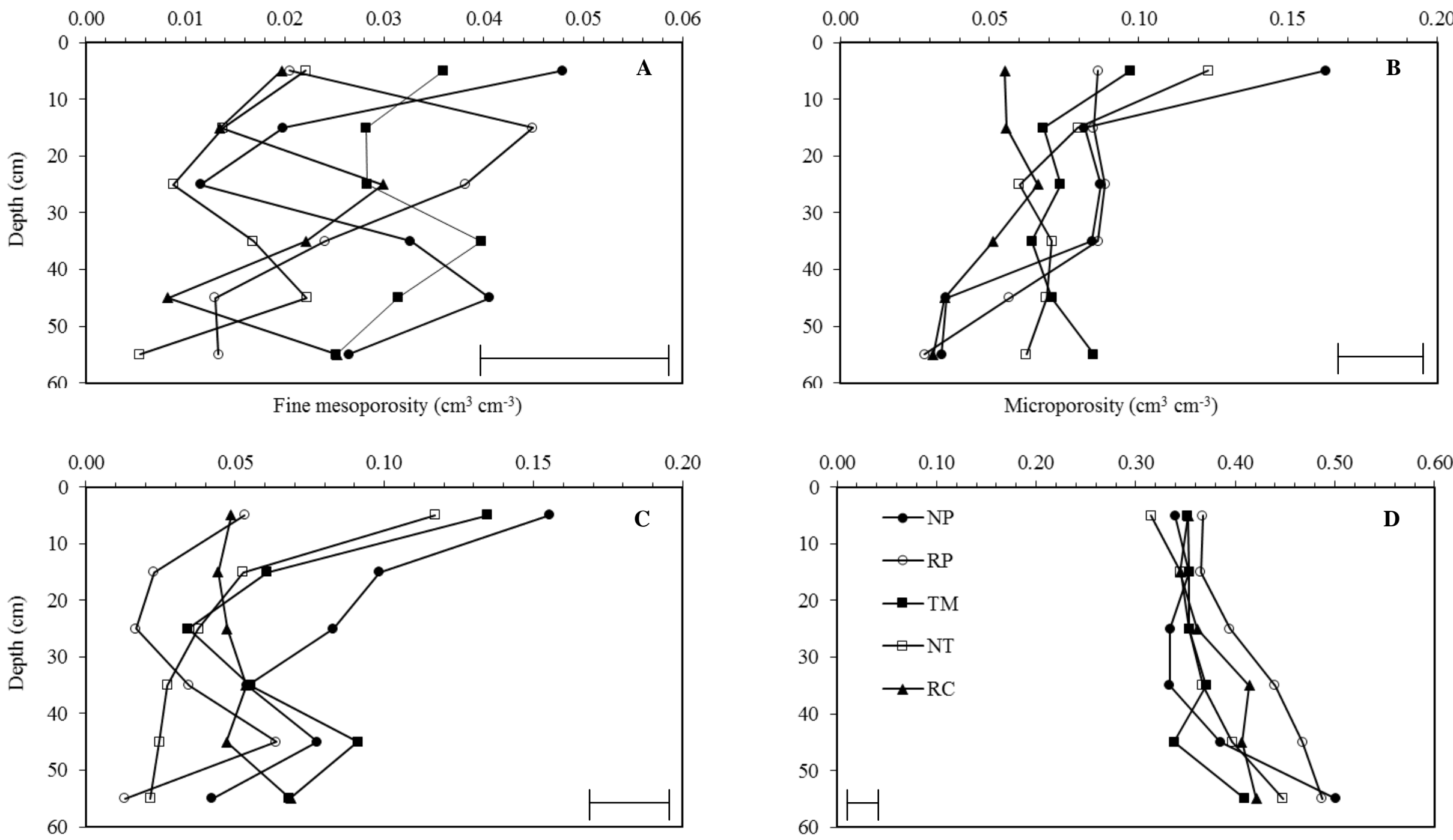

Figure 3. Macroporosity ( $>1,000 \mu \mathrm{m}$ diam, A), coarse mesoporosity (60 to 1,000 $\mu \mathrm{m}$ diam, B), fine mesoporosity, $(10$ to $60 \mu \mathrm{m}$ diam, C), and microporosity ( $<10 \mu \mathrm{m}$ diam, D) for native prairie (NP), restored prairie (RP), timothy grass (TM), no-till corn (NT) and row-crop (RC) treatments as a function of soil depth. Bars indicates least significant difference $(0.05)$ value. 


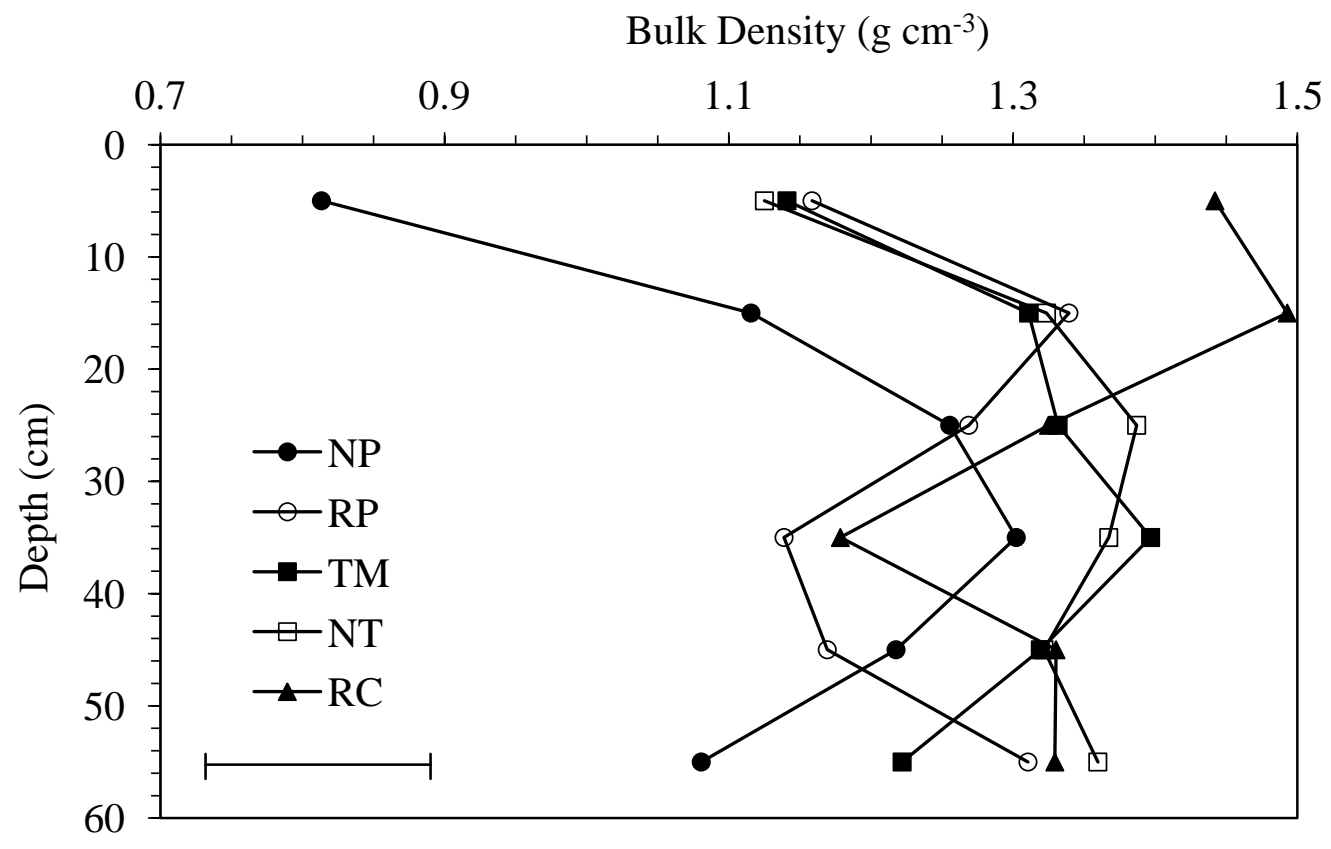

Figure 4. Bulk density for native prairie (NP), restored prairie (RP), timothy grass (TM), no-till corn (NT) and row-crop (RC) treatments by soil depth. The bar indicates the least significant difference $(0.05)$ value. 


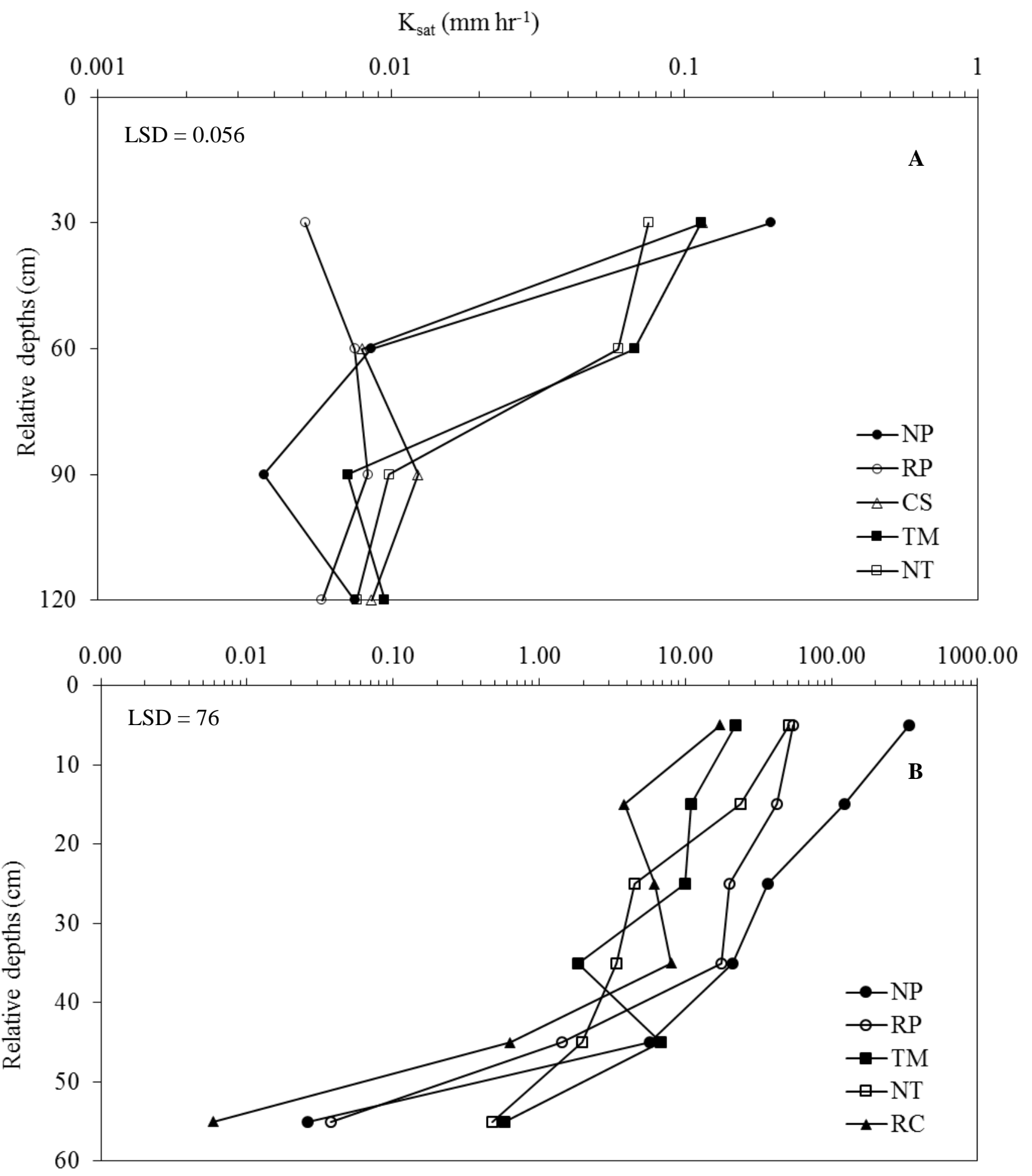

Figure 5. In situ (A) and laboratory measured (B) saturated hydraulic conductivity $\left(\mathrm{K}_{\mathrm{sat}}\right)$ for native prairie (NP), restored prairie (RP), timothy grass (TM), no-till corn (NT), row-crop (RC) and cover crop (CS) treatments as a function of depth. The cover crop (CS) treatment was only used to measure in situ saturated hydraulic conductivity $\left(\mathrm{K}_{\mathrm{sat}}\right)$. The values on the graphs represents least significant difference at $\alpha=0.05$ level. 